\title{
Inhibition of osteoblast activity by zoledronic acid
}

\author{
Inibição da atividade de osteoblastos expostos ao ácido zoledrônico
}

Fernanda Gonçalves Basso; Ana Paula Silveira Turrioni²; Josimeri Hebling 3 ; Carlos Alberto de Souza Costa ${ }^{4}$

\begin{abstract}
Introduction: Patients treated with nitrogen-containing bisphosphonates, such as zoledronic acid (ZA), have frequently shown oral bone exposure areas, termed osteonecrosis. In addition, these patients may also present low repair and regeneration potential, mainly after tooth extractions. These side-effects caused by bisphosphonates may be due to their inhibitory effects on oral mucosa and local bone cells. Objective: To evaluate the effects of ZA on the mineralization capacity of cultured osteoblasts. Materials and methods: Human immortalized osteoblasts (Sa0s-2) were grown in plain culture medium (Dulbecco's Modified Eagle Medium [DMEM] + 10\% fetal bovine serum [FBS]) in wells of 24-well plates. After 48-hour incubation, the plain DMEM was replaced by a solution with ZA at $5 \mu$ M which was maintained in contact with cells for seven, 14 or 21 days. After these periods, cells were evaluated regarding alkaline phosphatase (ALP) activity and mineral nodule formation (alizarin red). Data were statistically analyzed by Mann-Whitney test, at $5 \%$ of significance level. Results: ZA caused significant reduction on ALP activity and mineral nodules formation by cultured osteoblasts in all evaluated periods $(p<0.05)$. Conclusion: These data indicate that ZA causes inhibition on the osteogenic phenotype of cultured human osteoblasts, which, in turn, may reduce bone repair in patients subjected to ZA therapy.
\end{abstract}

Key words: osteonecrosis; repair; mineralization; osteoblasts.

\section{INTRODUCTION}

Bisphosphonates are indicated for the treatment of diseases characterized by intense bone resorption. Their main mechanism of action is inhibition of osteoclast maturation and activity. The use of these drugs has been linked to the development of osteonecrosis in the oral cavity, a condition that seems to be associated with the reduction of tissue repair capacity ${ }^{(2,3)}$.

Several studies demonstrate that bisphosphonates present inhibitory effect on different cell types, like osteoblast and epithelial cells, what may explain, at least partially, the development of osteonecrosis $^{(1,11,14)}$.

The zoledronic acid (ZA) is known as a potent bisphosphonate, particularly due to its greater capacity of adherence to the bone tissue $^{(9)}$. It is administered intravenously, with the frequency of use varying according to the disease to be treated and the established therapy ${ }^{(9)}$. Patients in treatment with this kind of bisphosphonate have presented higher risk for the development of osteonecrosis, what is directly related to the dose and the frequency of use ${ }^{(9)}$.

The etiopathogenesis of bisphosphonate-induced osteonecrosis has been associated with local traumas, like tooth extractions ${ }^{(6)}$. Besides, individuals treated with ZA also present low capacity for tissue repair and regeneration. This fact would explain the delay in the repair of bone and mucous tissue in patients treated with this $\operatorname{drug}^{(3,10)}$.

The low repair capacity after tooth extractions observed in patients treated with bisphosphonates may be related to a reduction in mineralization activity by local osteoblasts. Therefore, the objective of this study was to assess the mineralization capacity of osteoblasts exposed to ZA.

First submission on 13/10/12; last submission on 14/10/12; accepted for publication on $08 / 08 / 13$; published on 20/10/13

1. Doctorate in Oral Pathology from Faculdade de Odontologia de Piracicaba (FOP) of Universidade Estadual de Campinas (UNICAMP).

2. Master's degree in Dental Sciences from Faculdade de Odontologia de Araraquara (FOAr) of Universidade Estadual Paulista (UNESP); doctoral student of the Program of Dental Sciences at FOAr-UNESP.

3. Doctorate in Dental Sciences from FOAr-UNESP; associate professor of Pediatric Dentistry at the Children's Department of FOAr-UNESP.

4. Doctorate in Oral Biology and Pathology from FOP-UNICAMP; full professor of Oral Pathology at the Department of Physiology and Pathology of FOAr-UNESP. 


\section{MATERIALS AND METHODS}

\section{Cell culture}

An immortalized human osteoblast cell line was used (Sa0s-2 ATCC HTB-85). The cells, grown in plain culture medium (Dulbecco's Modified Eagle Medium [DMEM], GIBCO, Grand Island, NY, USA), containing antibiotics (100 IU/ml penicillin and $100 \mu \mathrm{g} / \mathrm{ml}$ streptomycin - GIBC0) and 10\% fetal bovine serum ([FBS] - GIBCO), were kept in incubation at $37^{\circ} \mathrm{C}$ with $5 \% \mathrm{CO}_{2}$, until the obtainment of the necessary number for the conduction of the experiment.

Thus, cells were seeded in wells of 24-well plates (Techno Plastic Products AG, Trasadingen, Switzerland), for 48 hours. Next, the complete DMEM was replaced by an osteogenic differentiation medium, characterized by the presence of $\beta$-glycerophosphate and ascorbic acid (Sima-Aldrich, St. Louis, MO, USA), but without the addition of FBS. Five $\mu$ M ZA (Novartis, São Paulo, SP, Brazil) were added to this new medium, which was put in contact with cells during seven, 14 and 21 days. The osteogenic medium was replaced every three days, with new addition of the drug, in the same concentration.

\section{Alkaline phosphatase (ALP) activity}

Cells exposure to the solution of ZA in the defined periods was followed by the assessment of alkaline phosphatase (ALP) activity, which is highly expressed by osteoblasts and takes part in the mineralization of the bone matrix. This assessment was conducted as described by Oliveira et $a l .{ }^{(7)}$. In general, the used protocol characterizes as a colorimetric endpoint assay, which produces, by means of a dephosphorylation reaction of thymolphthalein, a bluish solution, which may come in different shades according to the activity of the ALP enzyme present in the solution. This enzyme activity was determined spectrophotometrically (Termo Plate, Nanshan District, Shenzhen, China) by absorbance reading of the 590-nm solution. Its concentration is determined from a standard curve prepared according to the analysis of the known ALP concentrations.

\section{Formation of mineralized nodules (alizarin red)}

Osteoblast capacity to form mineralized nodules in culture was accomplished according to Idris et al. ${ }^{(5)}$. This assay reflects the capacity of these cells to form an organized and mineralized matrix, typical of bone tissue in the process of repair.

For the implementation of this protocol, cells were cultured in osteogenic differentiation medium during the experimental process (seven, 14 and 21 days). This medium provides the necessary substrates for the synthesis and deposition of components of the bone matrix by osteoblasts in culture.

After fixation in etanol $70 \%$ at $4^{\circ} \mathrm{C}$ and staining with alizarin red (40 mM, pH 4.2) (Sigma-Aldrich, St. Louis, MO, USA), it was possible to visualize the formation of mineralized nodules under an optical microscope (Olympus BX51, Miami, FL, USA), attached to a camera (Olympus C5060, Miami, FL, USA), for a qualitative analysis.

Part of the samples was subjected to quantitative analysis of mineralized nodule formation, which consists of the dissolution of the nodules in a cetylpyridinium chloride solution (Sigma-Aldrich). This dissolution results in the formation of a homogeneous solution, which is subjected to a spectrophotometric (Termo Plate) analysis of absorbance $(562 \mathrm{~nm})$.

\section{Statistical analysis}

Data on ALP and formation of mineralized nodules were assessed for normality. As these data did not present normal distribution, Mann-Whitney test was used, considering a significance level of $5 \%$.

\section{RESULTS}

Data on the ALP activity by osteoblasts (SaOs-2), according to treatment and assessment period, are presented on Table 1.

TABLE 1 - Alkaline phosphatase activity (\%) of Sa0s-2 cells, according to treatment and assessment period

\begin{tabular}{ccc}
\hline \multirow{2}{*}{$\begin{array}{c}\text { Period } \\
\text { (days) }\end{array}$} & \multicolumn{2}{c}{ Treatment } \\
\cline { 2 - 3 } & Control & Zoledronic acid \\
\hline 7 & $* 101.51(92.81-108.74) \mathrm{a} \mathrm{A}$ & $37.37(32.90-46.74) \mathrm{b} \mathrm{A}$ \\
14 & $99.04(95.87-105.05) \mathrm{a} \mathrm{A}$ & $16.86(16.62-17.33) \mathrm{b} \mathrm{B}$ \\
21 & $101.24(94.55-103.05) \mathrm{a} \mathrm{A}$ & $19.51(18.76-20.69) \mathrm{b} \mathrm{B}$ \\
\hline
\end{tabular}

Values are medians ( $25^{\text {th }}$ percentile- $75^{\text {th }}$ percentile), $\mathrm{n}=8$.

*Lower case letters allow the comparison in the lines; capital letters, in the columns. Values with the same letters do not differ statistically (Mann-Whitney, p > 0.05).

For the period of seven days, the group treated with ZA presented reduction of $64 \%$ in the ALP activity values when compared to the control group with no treatment $(\phi=0.001)$. In later periods, of 14 and 21 days, the same pattern of cellular response was observed, with an $82 \%$ reduction of ALP activity $(\phi=0.001)$ for both groups.

There were no differences in ALP activity for the control group in the three assessment periods $(p>0.05)$. For the group treated 
with ZA, the period of seven days presented the highest ALP values when compared to the other periods, with significant statistical difference $(p<0.05)$. The periods of 14 and 21 days did not differ from each other $(p>0.05)$.

The data on mineralized nodule formation by SaOs-2 cells, according to treatment and assessment period, are presented on Table 2.

TABLE 2 - Formation of mineralized nodules (\%) of $\mathrm{SaOs}-2$ cells, according to treatment and assessment period

\begin{tabular}{lcc}
\hline \multirow{2}{*}{$\begin{array}{c}\text { Period } \\
\text { (days) }\end{array}$} & \multicolumn{2}{c}{ Treatment } \\
\cline { 2 - 3 } & Control & Zoledronic acid \\
\hline 7 & $* 9.42(96.40-105.69) \mathrm{a} \mathrm{C}$ & $13.39(11.58-21.23) \mathrm{b} \mathrm{C}$ \\
14 & $110.04(107.40-114.53) \mathrm{a} \mathrm{B}$ & $27.09(18.91-37.08) \mathrm{b} \mathrm{B}$ \\
21 & $107.26(106.09-120.89) \mathrm{a} \mathrm{A}$ & $43.95(39.17-47.96) \mathrm{b} \mathrm{A}$ \\
\hline
\end{tabular}

Values are medians ( $25^{\text {th }}$ percentile- $75^{\text {th }}$ percentile), $\mathrm{n}=8$.

*Lower case letters allow the comparison in the lines; capital letters, in the columns. Values with the same letters do not differ statistically (Mann-Whitney, p > 0.05).

Cells treatment with ZA decreased mineralized nodule formation. In the period of seven days, the treated group suffered an $85 \%$ reduction on the values of mineralized nodule formation when compared to the control group $(p=0.001)$. In the periods of 14 and 21 days, the reductions were $83 \%$ and $63 \%$, respectively $(p=0.001)$.

When comparing the different assessment periods, the period of 21 days presented the highest values in nodule formation, followed by the periods of 14 and seven days, with a statistical difference among all of them $(\phi<0.05)$.

\section{DISCUSSION}

The results of this study show that human osteoblasts exposed to ZA presented a significant reduction in the capacity to produce components of matrix formation and mineralization. This was determined by the significant reduction of ALP activity by osteoblasts, which had their capacity to form mineralized nodules dramatically reduced. Within the limitations of the present study, one may suggest that these scientific data observed in cultured human osteoblasts could explain, at least partially, Allen's ${ }^{(3)}$ results. He demonstrated delay in bone repair in patients treated with this medicine.

Orris et al.$^{(8)}$ also studied the activity of human osteoblasts in culture, however the concentrations of ZA used by the authors were $10 \mathrm{~nm}, 100 \mathrm{~nm}, 1 \mu \mathrm{M}$ and $100 \mu \mathrm{M}$, which did not correspond to those found in the oral cavity of patients treated with this kind of bisphosphonate ${ }^{(12)}$. Despite the methodological differences, Orris et al. ${ }^{(8)}$ found results similar to those in this study, particularly related to the significant reduction in ALP and mineralized nodule production, which presented as dose- and time-dependent. Besides, previous studies demonstrated that ZA also promotes significant inhibition of the expression of type $\mathrm{I}^{(6,13)}$ collagen, main organic component of the bone matrix, what directly interferes in the process of tissue repair ${ }^{(4)}$.

By knowing the possible undesirable side-effects of ZA on the metabolism of different cell types and the resulting interference of this drug in the repair and regeneration process, perhaps other types of bisphosphonates might be used more safely. However, Idris et al. ${ }^{(5)}$ showed that other aminobisphosphonates, despite seeming less potent than ZA, also caused important negative effects on the activity of osteoblasts in vitro, as it was demonstrated in this and in previous studies ${ }^{(6,8,12,13)}$.

\section{ACKNOWLEDGEMENTS}

The authors thank Fundação de Amparo à Pesquisa do Estado de São Paulo (FAPESP) (2009/54722-1 and 2009/52326-1) and Conselho Nacional de Desenvolvimento Científico e Tecnológico (CNPq) (301291/2010-1) for the financial support for the conduction of this research.

\section{RESUMO}

Introdução: Pacientes em tratamento com bisfosfonatos, sobretudo com os nitrogenados, como o ácido zoledrônico (AZ), têm apresentado áreas de exposição de tecido ósseo na cavidade oral, caracterizadas como osteonecrose. Essas áreas apresentam limitada capacidade de reparo, principalmente após exodontias. Esses efeitos podem ser resultado do efeito inibitório causado por esse tipo de medicamento sobre as células da mucosa e do tecido ósseo local. Objetivo: Avaliar o efeito do AZ sobre a capacidade de mineralização de osteoblastos in vitro. Materiais e métodos: Foi utilizada uma linhagem celular de osteoblastos humanos (SaOs-2). As células foram cultivadas em meio de cultura completo (Dulbecco's Modified Eagle Medium [DMEM] + 10\% de soro fetal bovino [SFB]). Após 48 horas de incubação, o DMEM completo foi substituído por um novo DMEM sem SFB, ao qual foram 
adicionados 5 uM de AZ. Essa solução foi mantida em contato com as células por sete, 14 ou 21 dias. Após esse período, as células foram avaliadas quanto à atividade de fosfatase alcalina (ALP) e à produção de nódulos de mineralização (alizarin red). Os dados foram submetidos ao teste estatístico de Mann-Whitney, considerando nivel de significância de 5\%. Resultados: A exposição das células ao AZ causou redução significativa na atividade de ALP e na formação de nódulos mineralizados em todos os perídos avaliados ( $\mathrm{p}<0,05)$. Conclusão: Esses resultados revelam que o $\mathrm{AZ}$ causa alteração inibitória no fenótipo osteogênico das células bumanas em cultura, o que pode reduzir a capacidade de reparo do tecido ósseo após o contato com esse tipo de medicamento.

Unitermos: osteonecrose; reparo; mineralização; osteoblastos.

\section{REFERENCES}

1. AGIS, H. et al. Is zoledronate toxic to human periodontal fibroblasts? J Dent Res, v. 89, n. 1, p. 40-5, 2010.

2. ALLEN, M. R. et al. The pathogenesis of bisphosphonate-related osteonecrosis of the jaw: so many hypotheses, so few data. J Oral Maxillofac Surg, v. 67, n. 5, p. 61-70, 2009.

3. ALLEN M. R. The effects of bisphosphonates on jaw bone remodeling, tissue properties, and extraction healing. Odontology, v. 99, n. 1, p. 8-17, 2011.

4. HÄKKINEN, L. et al. Cell biology of gingival wound healing. Periodontology, v. 24, n. 1, p. 127-52, 2000.

5. IDRIS, A. et al. Aminobisphosphonates cause osteoblast apoptosis and inhibit bone nodule formation in vitro. Calcif Tissue Int, v. 82, n. 3, p. 191-201, 2008.

6. KOCH, F. P. et al. The impact of bisphosphonates on the osteoblast proliferation and collagen gene expression in vitro. Head Face Med, v. 6, p. 12-7, 2010.

7. OLIVEIRA, C. F. et al. In vitro effect of low-level laser on odontoblasticlike cells. Laser Phys Lett, v. 8, n. 2, p. 155-63, 2011.
8. ORRIS, I. R. Inhibition of osteoblast function in vitro by aminobisphosphonates. J Cell Biochem, v. 106, n. 1, p. 109-18, 2008.

9. OTTO, S. et al. Osteonecrosis of the jaw: effect of bisphosphonate type, local concentration, and acidic milieu on the pathomechanism. J Oral Maxillofac Surg, v. 68, n. 11, p. 2837-45, 2010.

10. POZZI, S. et al. High-dose zoledronic acid impacts bone remodeling with effects on osteoblastic lineage and bone mechanical properties. Clin Cancer Res, v. 15, n. 18, p. 5829-39, 2009.

11. SCHEPER, M. A. et al. Effect of zoledronic acid on oral fibroblasts and epithelial cells: a potential mechanism of bisphosphonate-associated osteonecrosis. Bri J Haematol, v. 144, n. 5, p. 667-76, 2008.

12. SCHEPER, M. A. et al. A novel bioassay model to determine clinically significant bisphosphonate levels. Support Care Cancer, v. 17, n. 12, p.1553-7, 2009.

13. SIMON M. J. K. et al. Expression profile and synthesis of different collagen types I, II, III, and V of human gingival fibroblasts, osteoblasts, and SaOS-2 cells after bisphosphonate treatment. Clin Oral Investig, v. 14, n. 1, p. $51-8,2010$.

14. WALTER, C. et al. Influence of bisphosphonates on endothelial cells, fibroblasts, and osteogenic cells. Clin Oral Invest, v. 14, n. 1, p. 35-41, 2010.

\section{MAILING ADDRESS}

Carlos Alberto de Souza Costa

Departamento de Fisiologia e Patologia; Faculdade de Odontologia de Araraquara; Universidade Estadual Paulista; Rua Humaitá, 1.680; Centro; Caixa postal: 331; CEP: 14801-903; Araraquara-SP, Brazil; Tel.: (16) 3301-6477; Fax: (16) 3301-6488; e-mail: casouzac@foar.unesp.br. 